\title{
INFLUENCE OF PLANTING DATE, PRE-SOWING TREATMENTS AND APPLICATION METHODS OF VARIOUS POTASSIUM SOURCES ON GROWTH, YIELD, QUALITY AND STORABILITY OF GARLIC (Allium sativum L.)
}

\section{Wafaa, A. Fekry}

Plant Production Department, Faculty of Technology and Development, Zagazig University, Egypt.

\section{ABSTRACT}

The present work was carried out in the Experimental Farm, Faculty of Technology and Development (Ghazala-Zagazig), Zagazig University, Sharkia Governorate during two successive winter seasons of 2013/2014 and 2014/2015, to assess the effect of two planting dates, $15^{\text {th }}$ September and $1^{\text {st }}$ October, pre-sowing treatments by soaking cloves, i.e. $250 \mathrm{ppm} \mathrm{GA}_{3}$, yeast extract $\left(4 \mathrm{~g} \mathrm{~L}^{-1}\right)$ and water (control) as well as four different sources and applications of potassium fertilizer, i.e. foliar spray of liquid potassium $\left(37.5 \% \mathrm{~K}_{2} \mathrm{O}\right)$, Potassium humate or thiosulphate at 3 $\mathrm{mlL}^{-1}$ integrated with the half recommended dose of potassium $(48 \mathrm{~kg}$ $\mathrm{K}_{2} \mathrm{O} / \mathrm{fed}$ ) for each as soil dressing and their interactions beside the control treatment $\left(96 \mathrm{kgK}_{2} \mathrm{O} / \mathrm{fed}\right)$ as soil dressing only without any foliar application on germination, growth, productivity and storability of garlic cv. Sids -40 .

The acquired results indicate generally that, early sowing date $15^{\text {th }}$ Sep. had enhancing effects on germination percentage, number of days to emergence, vegetative growth characters, yield and its components, as well as, quality and storability of bulbs. Soaking cloves at 250 ppm of $\mathrm{GA}_{3}$ for 12 hours as pre-sowing treatment increased the morphological traits, yield and its components, the chemical composition of plant and cloves as well as bulb storability. Foliar spray of potassium humate or thiosulphate at $3 \mathrm{mlL}^{-1}$ with $48 \mathrm{~kg} \mathrm{~K} \mathrm{~K}_{2} \mathrm{O} / \mathrm{fed}$ as soil dressing showed superior performance of all studied parameters. The best interaction values of most plant growth characteristics, i.e. plant height, No. of leaves, fresh and dry weight/plant, diameter of neck and bulb as well as bulbing ratio and yield components, i.e. physical characters of bulb, i.e. fresh and dry weight of bulb, fresh weight of clove and No. of cloves/bulb as well as total yield, exportable and marketable yield/fed and plant chemical composition, i.e. $N, P$ and $K$ content, cloves quality, i.e. N, P, K and total carbohydrates content as well as decreasing weight loss of bulbs during storage period were obtained by soaking 
cloves at $250 \mathrm{ppm}$ of $\mathrm{GA}_{3}$ for $12 \mathrm{hrs}$,pre- sowing at the early date $15^{\text {th }}$ Sep. and spraying plants with $3 \mathrm{mlL}^{-1}$ of potassium humate or thiosulphate with $48 \mathrm{~kg} \mathrm{~K}_{2} \mathrm{O} / f e d$ as soil dressing.

Conclusively, planting on $15^{\text {th }}$ of September after soaking cloves for 12 hours at $250 \mathrm{ppm}$ of $\mathrm{GA}_{3}$ and fertilized plants with $48 \mathrm{~kg} \mathrm{~K}_{2} \mathrm{O} / \mathrm{fed}$ as soil dressing combined with spraying $3 \mathrm{mlL}^{-1}$ with potassium humate or thiosulphate considered as much cheaper, easier and saver technique compared with the traditional methods of application of potassium fertilizer, could be recommended to produce the higher production and quality of garlic crop.

Key words: Planting dates, $\mathrm{GA}_{3}$, Yeast extract, Potassium humate and thiosulphate, Yield, Storability.

\section{INTRODUCTION}

Garlic (Allium sativum L.) is an important aromatic herbaceous plant belonging to family Alliaceae and widely used as a spice crop throughout the world (Rahman et al., 2006 and Swati et al., 2013).

Egypt occupy the fourth leading country in the world for garlic production (2.63.167 MT) after China, India and Bangladesh (FAO, 2014). Garlic cloves had a higher nutritive value than other bulb crops which contain proteins, carbohydrates, vitamins and lipids (Amagase, 2006). Moreover, it has different medicinal and functional properties (Zeinali and Moradi, 2015). Increasing garlic yield and improving bulb quality are essential target for both growers and consumers. Promoting garlic production is usually related with many factors, i.e. using the suitable cultivar, the appropriate planting dates, cultural practices as well as handling and storability conditions.

During growing season garlic plants were exposed to a different seasonal fluctuation of temperature and photoperiod, both having a strong effects on growth and development (Swati et al., 2013). The performance of garlic largely depends on the time of planting whereas the bulbing of garlic is controlled by the day length and temperature to which dormant cloves and growing plants are exposed before bulbing begins as vegetative growth requires short day and cool temperature while bulbing need long day and warm temperature (Subrata et al., 2010, Abdalla et al., 2011 and Choudhary, 2015). The early date of sowing garlic allows a longer growth period before bulbing and this resulting to strong plants producing better yield and bulb quality. In this regard, El-Zohiri and Farag (2014), Yossef and Tony (2014) and Hassan et al., (2016) revealed that early planting date (September) significantly dominated the late sowing dates in vegetative charactert. Moreover, they added that early planting had a pronounced effect on yield and its components, as well 
as quality and storability of bulbs. Similar results were obtained by Abdalla $e t$ al. (2011) when sowing garlic at the $1^{\text {st }}$ of September.

Seed cloves require more than four months at ambient temperature and relative humidity storage condition after harvesting because it had a dormancy which diminished gradually during storage (Rahman et al., 2006). Pre-sowing treatments of garlic cloves with soaking in growth promoting hormone $\left(\mathrm{GA}_{3}\right)$, neutral growth stimulants like yeast extract accelerated initiation, development and maturity of bulbs (Ahmed and Hemada, 2012, Woldeyes et al., 2017 and Woldeyes, 2017). As for Gibberellic acid $\left(\mathrm{GA}_{3}\right)$, it was known as a very efficient stimulating agent for breaking dormancy and promoting sprouting in different horticultural crops (Rahman et al., 2008 and Ouzounidou et al., 2011). The stimulative effect of soaking garlic cloves in $\mathrm{GA}_{3}$ solution were reported by Rahman et al., (2006), Ahmed and Hemada (2012) and Woldeyes et al., 2017, who concluded that soaking seed cloves in $\mathrm{GA}_{3}$ solution stimulate sprouting, vegetative growth through early growth behaviors, bulbing and yield as well as bulbs development and quality.

Brewers yeast as a bio-stimulant, is a microorganism capable of increasing its number and accelerating certain microbial process to increase the availability of nutrients elements in easy form to be taken by plants without pollution of the environment (Kraig and Hober, 1980). Dry yeast as a natural bio-substance serve as a good useful stimulatory, nutritional and protective functions when it is applied to vegetable plants due to its high contents of different nutrients, protein, vitamins especially B-complex as well as it enriched source of phytohormones (particularly cytokinins) which enhanced cell division and enlargement (Barnett et al., 1990 and Glick, 1995).

Brewers yeast is used as soil fertilization and extract as foliar application on the shoot of vegetable crops (Elsharkawy, 2013 as well as Shalaby and ElRamady, 2014). On the other hand, there were a rare studies on the effect of soaking garlic cloves or vegetable seeds in yeast extract on sprouting, growth and yield. In this respect, El-Desouky et al., (1998) on squash and Wanas (2002 and 2006 on faba bean and squash, respectively) reported that seed pre-sowing treatment with yeast extract increased growth parameters, yield and NPK contents in leaves. Moreover, Salama (1998), Ismaeil and Bakry (2005) on papaya, demonstrated that soaked papaya seed in yeast extract for 12 hours gave the highest values of germination parameters and vigorous vegetative growth.

Potassium is an essential major plant nutrient, which is needed by garlic plants to improve yield and its quality, as well as, prolong the period of storability. It helps in the transport of water and nutrients, influencing various biochemical and physiological processes like photosynthesis, respiration, protein synthesis, cell extension and wall thickness and stability. It is not only 
activates enzymes, but also it involves in the production of adenosine triphosphate (ATP), which might be regulate the rate of photosynthesis (Atkin and Macherel, 2009). Plants transport system uses energy in the form of ATP, consequently, if $\mathrm{K}$ is inadequate, ATP will less resulting to the breakdown of the transport system which in turn to poor yield and quality (Pal et al., 2016).

Increasing productivity with high quality is an important target of the garlic growers. Potassium fertilization considered as the most important practice for garlic production. As the result of chemical potassium fertilizers are very expensive, farmers minimized the amount used than the recommended dose and others ignored used it. The overcoming of this problem is agree with the steady trend to reduce the use of mineral fertilizers, specially soil applied and used foliar fertilization as an alternative or complementary to meet plant nutrient demand during the growing seasons and decrease the fertilizer cost which is a large portion of the crop production expenses (Ahmed et al., 2010).

Foliar fertilizers are widely used in vegetable crops, that contain macro and micronutrients which are more environmentally friendly and may increase growth, productivity as well as quality of yield. (Kolota and Osinska, 2001 and Haytova, 2013). Foliar feeding are fast acting because these are absorbed right at the site where they are used whereas leaves are green factories where the photosynthesis processes produce the compounds which needed to plant growth. There were different inexpensive potassium sources used as foliar application such as potassium humate or thiosulphate as well as liquid potassium $37.5 \% \mathrm{~K}_{2} \mathrm{O}$.

Potassium humate is a commercial product contains many elements necessary to the development of plant (Mohsen et al., 2017). It can be used as soil dressing, drenching or as foliar application. Changes in various metabolic process are detected within 8 hours after the application with humic substances (Pettit, 2009). Humic substances (HS) have been reported to influence plant growth. The mechanism of these effects are not fully clear. Some theories established that HS have the beneficial influences on physical, biological and chemical soil properties. The other mechanisms suggested that these compounds appeared for promotion plant growth through enhanced uptake of metallic ions and increasing cell permeability. Moreover, it could be mainly due to hormonelike activities of the humic substances through their involvement in cell respiration, photosynthesis, protein synthesis and various enzymatic reactions (Chen and Aviad, 1990). Several studies indicated that spraying garlic plants with humic acid enhanced plant growth, increased yield and quality as well as chemical composition of plants and bulbs (Denre et al., 2014; Mahmoud and Youssif, 2015; Zeinali and Moradi, 2015 and Mohsen et al., 2017). 
Potassium thiosulphate is more economical source of potassium which used as foliar spray. It was reported by many investigators that it increased plant growth, chemical constituents, yield and its quality (Shafeek et al., 2016 on garlic; Behairy et al., 2015 on onion and John and lester, 2011 on cantaloupe). The main purpose of the present study was to :

1) Evaluate the effects of planting date, soaking cloves as pre-sowing treatments in different stimulants, i.e. Gibberellic acid and yeast extract, as well as various sources and application methods of potassium fertilizer (soil dressing and foliar application) and their interactions on sprouting, plant growth, yield and its components, quality as well as storability of garlic bulbs.

2) Using foliar cheaper potassium sources as an alternative saving method of soil potassium fertilizer quantity application combining with reducing pollution.

\section{MATERIALS AND METHODS}

Field experiments were conducted during two winter seasons of 20132014 and 2014/2015 at Gazala Experimental Farm, Faculty of Technology and Development, Zagazig University, Sharkia Governorate, Egypt, to study the effect of two planting dates, pre-sowing treatments (soaking gloves) as well a different potassium sources and application methods on garlic cv. Sids-40 on germination, growth, yield and its components as well as chemical constituents of plants, cloves and bulb storability. The experimental field soil texture was clay, with $\mathrm{pH}$ 8.1-8.2, organic matter percentage 1.5-1.7 and available inorganic N22-20, P22-19 and K332-323 ppm in the first and second seasons, respectively. Chemical analysis of soil was performed according to methods described by Black (1982).

Average of maximum and minimum temperature $\left({ }^{\circ} \mathrm{C}\right)$ prevailed during the two experimental seasons 2013-2014 and 2014/2015 in Zagazig region are shown in Figure 1

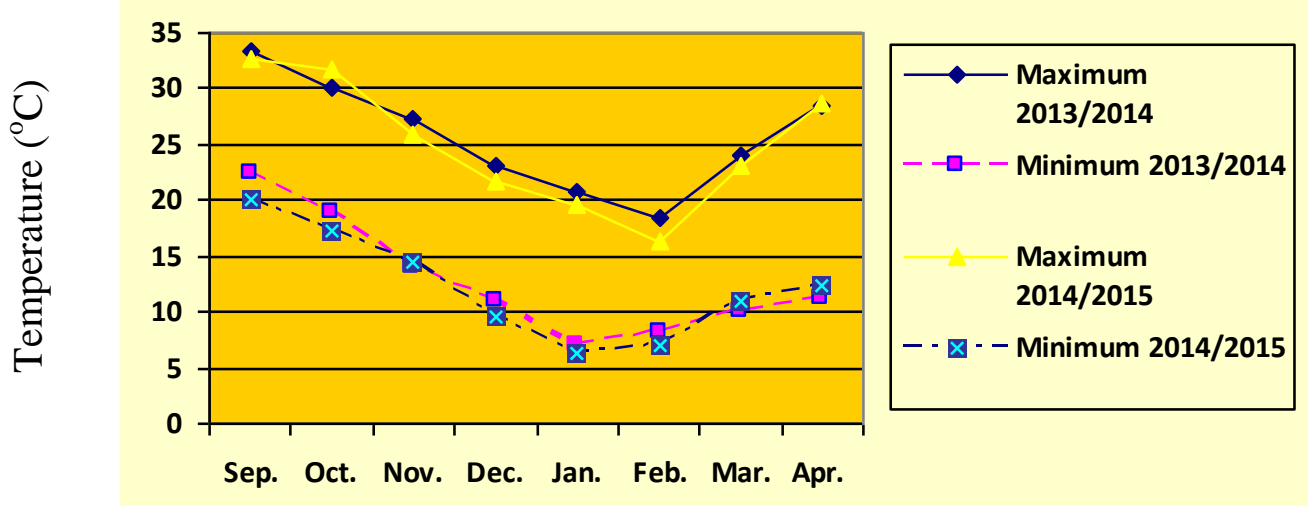


Figure 1: Average maximum and minimum temperature during the two growing seasons.

\section{The source: The National Authority for Meteorology.}

This experiment was set out in a split - split plots in a randomized complete blocks design with three replicates. The main plots were occupied with the two planting dates, while sub plots were allocated by pre-sowing treatment (soaking cloves), whereas potassium treatments were randomly distributed in the sub-sub plots. The experiment included 24 treatments which were the combinations between:

1- Two planting dates, i.e. $15^{\text {th }}$ September and $1^{\text {st }}$ October.

2- Pre-sowing treatment: Cloves were soaked for $12 \mathrm{hrs}$ before planting in the following treatments:
a) Water (control)
b) Gibberellic acid $\left(\mathrm{GA}_{3}\right)$ at $250 \mathrm{ppm}$.
c) Yeast extract $\left(4 \mathrm{gl}^{-1}\right)$.

3- Potassium treatments (sources and applications).

a) $96 \mathrm{~kg} \mathrm{~K} \mathrm{~K}_{2} \mathrm{O} / \mathrm{fed}$ (Control, the recommended dose) in the form of potassium sulphate $\left(48 \% \mathrm{~K}_{2} \mathrm{O}\right)$ as soil dressing.

b) $48 \mathrm{~kg} \mathrm{~K}_{2} \mathrm{O} /$ fed (Soil dressing) + liquid potassium $37.5 \% \quad \mathrm{~K}_{2} \mathrm{O}$ at $3 \mathrm{mlL}^{-1}$ (foliar application).

c) $48 \mathrm{~kg} \mathrm{~K}_{2} \mathrm{O} / \mathrm{fed}$ (Soil dressing) + Potassium thiosulphate at $3 \mathrm{mlL}^{-1}$ (foliar application).

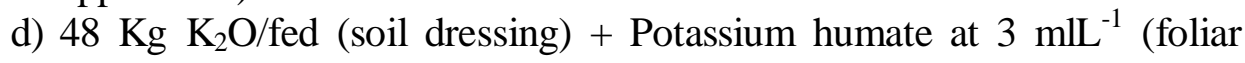
application) .

Sources of foliar potassium fertilizers:

1- Liquid potassium (LK), 37.5\% $\mathrm{K}_{2} \mathrm{O}$, Kafr El Zayat Pesticides \& Chemicals Co., Egypt.

2- Potassium thiosulphate (KTS), containing $25 \% \mathrm{~K}_{2} \mathrm{O}$ and $17 \%$ sulpher .

3- Potassium humate $(\mathrm{KH})$, consists of potassium humate (20\%) and sulpher $(4.32 \%)$.

Both Potassium thiosulphate and humate were obtained from El Salhia for Intermediate chemicals Co., Egypt. Yeast extract was prepared from brewer's yeast. (Saccharomyces cerevisiae), dissolved in water followed by adding sugar at a ratio of 1:1 and kept 24 hours in a warm place for reproduction.

Foliar potassium treatments were sprayed four times, first one after 30 days of emergence and then every 15 days. Soil potassium application, i.e. potassium sulphate $\left(48 \% \mathrm{~K}_{2} \mathrm{O}\right)$ were added at three equal portions 30, 60 and 90 days after emergence. All plants were fertilized with $300 \mathrm{~kg}$ of ammonium sulphate $(20.5 \%$ 
$\mathrm{N})$ and $200 \mathrm{Kg}$ of calcium superphosphate $\left(15.5-16 \% \mathrm{P}_{2} \mathrm{O}_{5}\right)$ per feddan. Nitrogen was applied one, two and three months after emergence, while phosphorus, two times, the first during preparing the soil and the second after two months from emergence. Each experimental plot area was $8.4 \mathrm{~m}^{2}$ (3 ridges, each $4.0 \mathrm{~m}$ long and $0.7 \mathrm{~m}$ width). Soaked cloves were planted upright with apical tip exposed at $10 \mathrm{~cm}$ apart on both sides of ridge. Other agricultural practices of growing garlic plants were carried out as commonly followed in the district.

\section{Data recorded:}

\section{Germination parameters:}

1- Germination percentage after 30 days from planting date by counted the germinated cloves and then used the following formula:

$$
\text { Germination percentage }=\frac{\text { Number of germinated cloves } / \text { plot }}{\text { Total number of planted cloves } / \text { plot }} \times 100
$$

$2-$ Count the number of days to emergence.

\section{Plant growth characters:}

A random sample of ten plants was taken from each experimental plot at 140 days after planting in both seasons and the following data were recorded, plant height, number of leaves per plant, fresh and dry weight of plant (foliage + bulbs), as well as neck and bulb diameter. Bulbing ratio was calculated by using the following formula described by Mann (1952). Bulbing ratio $=$ Neck diameter/Bulb diameter.

\section{Yield and its components:}

When the older leaves turned yellowish green and had started withering, plants of each plot were harvested and left to be cured for two weeks in open shady place. After that, the following parameters were recorded:

a- Physical characters of bulb: A random sample of ten bulbs was taken from each plot to record: bulb fresh and dry weight, number of cloves/bulb as well as cloves/bulb and clove fresh weight.

b- Yield and its grades: Bulbs of each experimental unit were graded into four categories according to specification laid down by Egyption Ministry of Economic for garlic exportation (1963) as follows: Grade 1: Bulbs with diameter above $5.5 \mathrm{~cm}$. . Grade 2: bulbs with diameter between $4.5-5.5 \mathrm{~cm}$. Grade 3: bulbs with diameter between $3.5-4.5 \mathrm{~cm}$. Grade 4: Bulbs with diameter less than $3.5 \mathrm{~cm}$.

Each grade was weighed separately and the following data were recorded: 1-Exportable yield (grade $1+$ grade 2 ).

2-Marketable yield (grade $1+$ grade $2+$ grade 3 ) 
3-Total yield was calculated by sum the all grades from one to four.

\section{Chemical composition of plant and cloves:}

a- Chemical composition of plant: At 140 days after cultivation a sample of $100 \mathrm{~g}$ from fresh weight of each foliage and bulbs of each treatment were dried at $70^{\circ} \mathrm{C}$ till constant weight. Nitrogen, phosphorus and potassium were determined in the digested mixture dry matter of leaves and bulbs according to the methods described by Bremner and Mulvaney (1982), Olsen and Sommers (1982) and Jackson (1970), respectively.

b- Chemical composition of cloves: A sample of $50 \mathrm{~g}$ of cloves from each treatment were oven dried till constant weight, ground and digested to determine total nitrogen, phosphorus and potassium according to the same methods described previously in plant chemical composition, as well as total carbohydrates as depicated by Dubois et al., (1956).

\section{Storability of garlic bulbs:}

Samples of cured garlic (5 kg of marketable yield) from each sub-sub plot in both seasons were stored under normal room conditions and the loss of total weight percentage was monthly recorded through nine months of storage.

\section{Statistical analysis:}

The obtained data were statistically analyzed by using the SPSS software according to Pallant (2001). Means separation was done by using LSD at 0.05 level of probability.

\section{RESULTS AND DISCUSSION}

\section{Germination parameters}

Data illustrated in Table 1 indicate that there were significant differences between the two planting dates and the soaking cloves treatments of germination percentage and the number of days to emergence.

\section{1- Germination percentage:}

Results presented in Table 1 reveal that the maximum germination percentages ( 88.11 and $86.77 \%$ ) in the two growing seasons, respectively were recorded on the early planting $15^{\text {th }}$ Sep. At late sowing $1^{\text {st }}$ October, decrease in germination may be refer to temperature fluctuation. Obtained results are in agreement with those reported by Choudhary (2015) who reported that the favourable agro climatic conditions prevailed with early sowing have improved the germination of garlic cloves and seedling emergence than the delayed dates. Also, El-Zohiri and Farag (2014) on garlic and El-Helaly and Karam (2012) on 
onion suggested that at late planting the temperature can not fulfill the temperature requirement for seed germination.

Regarding mean values of soaking treatments, results in Table 1 indicate that the two tested treatments had significant increase in germination percentage as compared with control (soaking in water). The

Table 1 : Effect of planting date and pre-sowing soaking treatments on germination parameters during 2013-2014 and 2014-2015 seasons.

\begin{tabular}{|l|c|c|c|c|}
\hline \multirow{2}{*}{ Treatments } & \multicolumn{2}{|c|}{ Season 2013-2014 } & \multicolumn{2}{c|}{ Season 2014-2015 } \\
\cline { 2 - 5 } & $\begin{array}{c}\text { Germination } \\
\text { percentage }\end{array}$ & $\begin{array}{c}\text { No. of days to } \\
\text { emergence }\end{array}$ & $\begin{array}{c}\text { Germination } \\
\text { percentage }\end{array}$ & $\begin{array}{c}\text { No. of days } \\
\text { to } \\
\text { emergence }\end{array}$ \\
\hline Planting date $(\boldsymbol{A}):$ & 88.11 & 22.90 & 86.77 & 21.48 \\
\hline $15^{\text {th }}$ September & 85.80 & 26.61 & 84.77 & 25.58 \\
\hline $1^{\text {st }}$ October & $\mathbf{2 . 3 6}$ & $\mathbf{5 . 6 4}$ & $\mathbf{0 . 4 0}$ & $\mathbf{0 . 7 8}$ \\
\hline L.S.D at 0.05 & 84.65 & 26.66 & 83.99 & 25.68 \\
\hline Soaking cloves treatments $(\boldsymbol{B}) \mathbf{:}$ & \multicolumn{5}{|l|}{} \\
\hline Water $($ control $)$ & 89.49 & 22.75 & 87.66 & 21.45 \\
\hline Gibbrellic acid $\left(\mathrm{GA}_{3}\right)$ & 86.73 & 24.85 & 85.67 & 23.47 \\
\hline Yeast extract & $\mathbf{1 . 2 8}$ & $\mathbf{1 . 2 4}$ & $\mathbf{1 . 5 5}$ & $\mathbf{0 . 9 0}$ \\
\hline L.S.D at 0.05 &
\end{tabular}

best results were obtained by soaked garlic cloves at $250 \mathrm{ppm}$ of $\mathrm{GA}_{3}(89.49$ and $87.66 \%$ ) followed by the treatment yeast extract $(86.73$ and $85.67 \%)$ in the two seasons, respectively. In this concern, Rahman et al., (2006 and 2008) as well as Ahmed and Hemada (2012) observed that $\left(\mathrm{GA}_{3}\right)$ considered as a very efficient stimulating factor for breaking dormancy and increased sprouting of garlic gloves.

In this respect, Woldeyes et al., (1017) stated that presence of appropriate level of $\mathrm{GA}_{3}$, which accumulates in dormant seeds during cold storage and/or when exogenously applied, stimulates the synthesis, activation and secretion of hydrolytic enzymes, releasing reducing sugars and amino acids which are needed for garlic sprouting. As for the effect of yeast extract, Salama (1998), as well as, Ismaeil and Bakry (2005) reported

that the best result of germination percentage of papaya seeds was obtained by soaking in yeast extract.

The interaction between planting dates and soaking cloves treatments had no significant effect during the two growing seasons, whereas the higher germination percentages $(90.5$ and $88.83 \%$ ) were showed by soaking cloves ins $\mathrm{GA}_{3}$ solution for 12 hours and then sowing on $15^{\text {th }}$ Sep. in both seasons, respectively, as shown in Table 2. 


\section{2- Number of days to emergence:}

The two planting dates have a significant effect on the number of days to emergence. It is obvious from such data in Table 1, that the minimum days to emergence (22.90 and 21.48) were observed on the early planting Table 2 : Interaction effect among two planting dates and pre-sowing soaking treatments on germination parameters during 20132014 and 2014-2015 seasons.

\begin{tabular}{|c|c|c|c|c|c|}
\hline \multirow{2}{*}{\multicolumn{2}{|c|}{ Characters }} & \multicolumn{2}{|c|}{ Season 2013-2014 } & \multicolumn{2}{|c|}{ Season $2014-2015$} \\
\hline & & \multirow{2}{*}{$\begin{array}{c}\begin{array}{c}\text { Germination } \\
\text { percentage }\end{array} \\
85.76 \\
\end{array}$} & \multirow{2}{*}{$\begin{array}{c}\begin{array}{c}\text { No. of days to } \\
\text { emergence }\end{array} \\
25.26\end{array}$} & \multirow{2}{*}{$\begin{array}{c}\begin{array}{c}\text { Germination } \\
\text { percentage }\end{array} \\
84.43\end{array}$} & \multirow{2}{*}{$\begin{array}{c}\begin{array}{c}\text { No. of days to } \\
\text { emergence }\end{array} \\
23.66 \\
\end{array}$} \\
\hline \multirow{3}{*}{ in } & Water ( control ) & & & & \\
\hline & Gibbrellic acid $\left(\mathrm{GA}_{3}\right)$ & 90.50 & 20.41 & 88.83 & 19.43 \\
\hline & Yeast extract & 88.06 & 23.03 & 87.06 & 21.36 \\
\hline \multirow{4}{*}{$\ddot{\sigma} \ddot{0}$} & Water ( control ) & 83.53 & 28.06 & 83.55 & 27.70 \\
\hline & Gibbrellic acid $\left(\mathrm{GA}_{3}\right)$ & 88.48 & 25.10 & 86.50 & 23.46 \\
\hline & Yeast extract & 85.40 & 26.67 & 84.28 & 25.57 \\
\hline & L.S.D at 0.05 & N.S & N.S & N.S & N.S \\
\hline
\end{tabular}

$\left(15^{\text {th }} \mathrm{sep}\right)$, whereas the maximum days to emergence (26.61 and 25.58$)$ were recorded when cloves planted on $1^{\text {st }}$ Oct. in the first and second seasons, respectively. In this respect, Abu-Rayyan et al., (2012) on onion and ElZohiri and Farag (2014) on garlic stated that early planting was the most efficiency for lessen the number of days to emergence, this may be due to the prevailing high temperature which needed for germination period during early planting. On the contrary, delayed sowing date of garlic cloves delayed the emergence of plants as a result of exposure to unsuitable low temperature germination.

Concerning the effect of soaking treatments on the number of days to emergence, data presented in Table 1 show that soaking cloves as presowing treatments had statistically significant differences in this respect. The fewer days to emergence ( 22.75 and 21.45$)$ by were detected soaking in $\mathrm{GA}_{3}$ followed by yeast extract (24.85 and 23.47) compared with the control (water), respectively during both seasons of growth. Such promoting effect of soaking generally on speedy germination and early emergence may be attributed to the mobilize antioxidant enzymes which subordinate per oxidation in seeds which retain seed vigor causing earlier emergence (Saleem et al., 2014). Obtained results of soaking garlic cloves in $\mathrm{GA}_{3}$ are in conformity with those found by Takagi (1990), Rahman et al., (2006 and 2008) and Woldeyes et al., (2017) who stated that seedling emergence in garlic has been enhanced by cloves treated with $\mathrm{GA}_{3}$. 
In this concern, Ray Noggle and Fritz (1992) as well as Ismaeil, and Bakry (2005) stated that soaking in yeast extract caused significant improvement in germination rate. 
Combination between planting date and soaking treatments on the number of days to emergence were represented in Table 2. The two planting dates and various soaking treatments had no significant differences in this respect. The best results (minimum days to emergence) were found by soaking seeds in $\mathrm{GA}_{3}$ (20.41 and 19.43) followed by yeast extract (23.03 and 21.36) and sowing on the first planting date $\left(15^{\text {th }}\right.$ Sep.) during both seasons of study, respectively.

\section{Plant growth characters}

Data in Table 3 show the effect of the two planting dates, pre-sowing treatments (soaking cloves) and various sources and application methods of potassium fertilizer on vegetative growth characters of garlic plants. As for the effect of planting date, tested treatments had a significant differences on most the studied growth aspects in both growing seasons . Early planting date $\left(15^{\text {th }}\right.$ Sep.) played a significant role on enhancing the growth of plants. It produced the tallest

plants and increased fresh and dry weight of plant, neck and bulb diameter as well as bulbing ratio.

Improvement of vegetative growth attributes by early planting might be due to the fact that sowing crop either too early or delay adversely affected the growth as a result of variation in maximum and minimum temperature (Choudhary, 2015). The promotive effect of early sowing on vegetative parameters may be due to the plants exposed to cool temperature and short day length which encourage meristematec elongation that enhanced the vegetative growth before the formation of bulb (El-Zohiri and Farag, 2014; Youssef and Tony, 2014 and Hassan et al., 2016). As for the beneficial effect of early planting $15^{\text {th }}$ Sep. on increasing neck diameter whereas decreased with delaying planting, El-Zohiri and Farag (2014) reported that delayed planting make plants hadn't complete their growth and development stages as well as the production and accumulate of photo assimilates. The results is in agreement with the findings of Ahmed, 2002; Rahim et al., 2003 and Swati et al., 2013.

Concerning the effect of soaking cloves treatments, data in Table 3 show that the highest values for all parameters were obtained by soaking gloves in $\mathrm{GA}_{3}$ at $250 \mathrm{ppm}$ for 12 hours. Moreover, the differences between soaking in yeast extract or water hadn't differed significantly during both seasons of growth. Such results are in harmony with those reported by Ouzounidou et al., (2011), Ahmed and Hemada (2012), Woldeyes (2017) all working on garlic and Geletie (2016) and El-Hamady (2017) on potato. The promoting effect of Gibberellic acid on plant growth may be 
responsible for cell division and elongation in meristematic areas and this promote vegetative growth including the elongation of stems and expansion of leaves (Geletie, 2016).

In this concern, the little increment effect of yeast extract on vegetative traits may be due to that yeast is account as a natural source of some growth regulators (Glick, 1995 and Twfiq, 2010). They reported that yeast was capable of increasing the stimulative growth compounds like gibberellins, cytokinins and auxins which act in improving plant cell division and enlargement. As well as it contains sugar, amino acids and vitamins, especially B which may play an important role in improving growth. Similar results were obtained by El-Desouky (1998) and Wanas (2006) on squash who found that soaking squash seeds in yeast extract encouraged plant growth.

With respect to potassium sources and application methods data presented in Table 3 revealed that potassium foliar application treatments i.e. liquid potassium or potassium thiosulphate or humate combined with half of the recommended dose of chemical potassium fertilizer $(48 \mathrm{~kg}$ $\mathrm{K}_{2} \mathrm{O} / \mathrm{fed}$ ) had a significant effects on most growth measurements. The highest values of all growth traits were obtained by the treatment $48 \mathrm{~kg}$ $\mathrm{K}_{2} \mathrm{O} / \mathrm{fed}$ as soil dressing with foliar application of potassium humate followed by thiosulphate,liquid potassium and the recommended dose of soil dressing in a descending. These results were true in the first and second season of study. The increment in growth parameters by spraying potassium humate may be due to hormone - like activities of the humic acids through their involvement in cell respiration and permeability, photosynthesis, oxidative phosphorolation, protein synthesis and various enzymatic reactions (Chen and Aviad, 1990; Nardi et al., 2002, and Chen and Magan, 2004). These results are in agreement with those of Mahmoud, and Youssif, (2015), Zeinali and Moradi (2015) and Mohsen et al., (2017) on garlic and Shafeek et al., (2016) on cucumber. The promotive effect of plant growth with the addition of Potassium thiosulfate probably attributed to the synergestic action of both potassium and sulfur which it consists from them. K-element had a great role in controlling various enzymes activities, protein synthesis, nutrients translocation, root formation as well as increased the efficiency of plant to utilize nitrogen which improving plant metabolism, enhancing merstimatic activity and leaves growth (Chen et al., 2004). In this respect, Huber (1985) as well as Mengle and Kirkby (1987) suggested that the increase of plant growth due to potassium plays a vital role in plant metabolism such as photosynthesis, translocation and photosynthetic substates. Moreover, sulfur considered as one of the three secondary 
nutrients (calcium and magnesium) required by plants for normal, healthy growth which it is a vital part of all plants proteins and certain plant hormones (Marschner, 1995).

These results are in accordance with those reported by Behairy et al., (2015), Shafeek et al., (2016) on garlic, John and Lester (2011) on cantaloupe and Haytova (2013) on different crops. In addition, potassium sulfate could affect soil through the role of sulphate (which act as acidic component) for minimizing the values of soil $\mathrm{pH}$ and subsequently, facilitate the absorption of nutrients by plant roots (Taha et al., 2016).

\section{Interaction effect between planting date and soaking cloves treatments:}

Various soaking treatments combined with the two planting dates showed significant differences in most vegetative growth characters (Table 4). In this respect, the early planting date $\left(15^{\text {th }}\right.$ Sep.) with pre-soaking cloves in $\mathrm{GA}_{3}$ or yeast extract in the second order showed the highest vegetative parameters, during the two growing seasons except No of leaves/plant and neck diameter in the second season as well as bulbing ratio in both seasons. These results may be referring to the favourable environmental conditions especially optimum temperature to germination of garlic cloves. Furthermore its seedling and plant growth attributes (Choudhary, 2015), beside the influence of $\mathrm{GA}_{3}$ on early growth and its role in stem elongation and leaf extension (Rahman et al., 2008).

\section{Interaction effect between planting date and potassium fertilizer sources and application methods:}

The interaction effect between the two planting dates $\left(15^{\text {th }}\right.$ Sep. and $1^{\text {st }}$ Oct.) and the half recommended dose of potassium fertiliszer as soil dressing ( $48 \mathrm{~kg} \mathrm{~K}_{2} \mathrm{O} / \mathrm{fed}$ ) with different potassium forms (Liquid potassium $37.5 \mathrm{~K}_{2} \mathrm{O}$, potassium thiosulphate or humate as foliar application reflected significant differences in studied parameters except No. of leaves/plant in both seasons as well as neck diameter in the second one compared with control treatment as shown in Table 4. Cultivate garlic cloves in $15^{\text {th }} \mathrm{Sep}$. and fertilized with $48 \mathrm{~kg} \mathrm{~K}_{2} \mathrm{O} / \mathrm{fed}$ as soil dressing and sprayed plants with potassium humate $3 \mathrm{mlL}^{-1}$ gave the highest values in this respect. These results are in agreement with those of Mohsen et al., (2017)who reported that foliar spray of potassium humate had enhanced effects on growth parameters of garlic plants.

\section{Interaction effect between soaking cloves and potassium treatments:}

Results in Table 4 show the effect of interaction between the presoaking garlic cloves in $\mathrm{GA}_{3}$, yeast extract and water (control) and potassium sources, i.e. liquid potassium $\left(37.5 \% \mathrm{~K}_{2} \mathrm{O}\right)$, potassium humate and 
thiosulphate as foliar application as well as $48 \mathrm{~kg} \mathrm{~K}_{2} \mathrm{O} / \mathrm{fed}$ as soil dressing on morphological characters of garlic plants. Obtained data show the significant action of this interaction for all studied parameters in both growing seasons except the number of leaves in the second one. It is obvious from results in Table 4. that pre-soaking cloves in solution of $250 \mathrm{ppm} \mathrm{GA}_{3}$ and applied plants with $48 \mathrm{~kg} \mathrm{~K}_{2} \mathrm{O} / \mathrm{fed}$ as soil dressing in combination with potassium humate as foliar spray was the best treatment in this concern which achieved the highest values of all growth characters in both seasons.

\section{Yield and its components}

a) Physical characters of bulb:

Data presented in Table 5 reveal the effect of two planting dates, soaking cloves treatments and potassium fertilizer treatments on the physical characters of garlic bulb. Such data show that planting dates had a significant effect on bulb features in both growing seasons except number of cloves in the two seasons.

Early planting $\left(15^{\text {th }}\right.$ Sep.) resulted to obtain higher value of all studied physical characters, i.e. fresh and dry weight of bulb, fresh weight of cloves, clove as well as number of cloves per bulbes compaired with late planting date( $1^{\text {st }}$ Oct.).

In this regard, Youssef and Tony (2014) stated that bulb size and weight as well as clove weight and number of cloves /bulb influenced by planting date, growth environment and cultivar. The enhancement of early sowing date of bulb characters may be due to that plants were exposed to enough period of cool temperature and short day length which promote the vegetative growth of plants before the formation of its bulbs, these conditions resulting to more assimilation and translocation of carbohydrates to the cloves, leading to increase the weight of both clove and bulb. These results are going in line with those reported by Subrata et al., (2010), Abdalla et al., (2011), Swati et al., (2013), El-Zohiri and Farag (2014), Choudhary (2015) and Hassan et al., (2016).

As for cloves soaking treatments, it is clear from the data in Table 5 that $\mathrm{GA}_{3}$ followed by yeast extract significant increase bulb fresh and dry weight as well as cloves fresh weight during the two growing seasons except No. of cloves /bulb and clove fresh weight in the first and second season, respectively compared with the control treatment (water). Pre-planting soaking cloves in solution contain $250 \mathrm{ppm} \mathrm{GA}$ reflected the maximum increase in all studied parameters during the both seasons of growth. In this concern, the increment of bulb features are related with the improve of vegetative growth which shown in Table 3 and this consequently affect yield and its parameters. These results are in agreement with those reported by Ahmed and Hemada (2012) and Woldeyes (2017) on garlic. The enhancement of garlic bulb characters by soaking in yeast extract might be ascribed to its enhancing effects on plant growth and dry 
matter accumulation which increased bulb quality. Similar conclusions had been shown on different crops, i.e. El-Desouky (1998) and Wanas (2006) on Squash and Wanas (2002) on faba bean when utilizated yeast extract as seedsoaked material.

With concern to the effect of potassium fertilizer sources and application methods on bulb physical characters, it is clear from the data in Table 5 that there were significant increase in bulb fresh and dry weight, fresh weight of cloves and clove as well as number of cloves/bulb by different sources of potassium during the two seasons of study except the number of cloves/bulb in the second season. In this respect, spraying plants with potassium humate combined with $48 \mathrm{~kg} \mathrm{~K} 2 \mathrm{O} / \mathrm{fed}$ as soil dressing reflected the maximum increase in all studied characters and followed by thiosulphate application during both seasons of growth compared with the control.

Such results were confirmed by those obtained by Abdel-Razzak and ElSharkawy, (2013), Mahmou, and Youssif, (2015) and Mohsen et al., (2017) on garlic.

\section{Interaction effect of planting date and soaking cloves treatments:}

It is clear from the data in Table 6 that there were significant effect of the interaction between planting date and soaking treatments $\left(\mathrm{GA}_{3}\right.$, yeast extract and water) on most garlic bulb parameters. The highest values of bulb physical characters were obtained by pre-soaking gloves in $\mathrm{GA}_{3}$ and planting at the early date $15^{\text {th }}$ Sep. These results are in harmony with those reported by Choudhary (2015) who stated that garlic is a thermo and photosensitive crop and its plant growth, bulb formation and development are greatly affected by growing environment.

\section{Interaction effect of planting date and potassium fertilizer sources and application methods:}

Results in Table 6. Show that the significant increment of bulb studied characters were obtained by sowing cloves in $15^{\text {th }}$ Sep. and fertilized with $48 \mathrm{~kg} \mathrm{~K}_{2} \mathrm{O} /$ fed as soil application and potassium humate at $3 \mathrm{mlL}^{-1}$ as foliar spray.

These results were confirmed by Ahmed et al., (2010) on garlic, who suggested the possibility to applying this treatment as an alterative method of potassium application to fertilize garlic plants.

\section{Interaction effect between soaking cloves and potassium treatments:}

Data in Table 6 reveal the significant differences among the interaction treatments on the physical characters of garlic bulbs during both 
seasons of the experiment except number of cloves/bulb in the second season. The enhanced effect of bulb parameters were observed by presoaking gloves in $\mathrm{GA}_{3}$ as well as potassium humate or thiosulphate at $3 \mathrm{mlL}^{-1}$ as foliar spary and fertilized plants by $48 \mathrm{~kg} \mathrm{~K}_{2} \mathrm{O} / \mathrm{fed}$ (soil application).

\section{b) Yield and its grades:}

Data in Table 7 illustrate the effect of planting date on yield of different grades according to bulb size, exportable, marketable and total yield (ton/fed) of garlic bulb. There were significant differences between the two planting dates for most studied parameters. Sowing garlic in $15^{\text {th }}$ Sep. gave the highest values of total yield, exportable, marketable yield (ton/fed) in both growing seasons. From such data, it is also clear that early planting $\left(15^{\text {th }}\right.$ Sep.) gained the highest values of weight of $1^{\text {st }}$ grade (bulbs diameter above $5.5 \mathrm{~cm}$ ), while the highest values of weight of the $2^{\text {nd }}, 3^{\text {rd }}$ and $4^{\text {th }}$ grades were obtained by sowing garlic on $1^{\text {st }}$ Oct. The effect of early planting for yield increments may related with the increase of number of cloves, size and weight of clove and bulb by early planting as shown in Table 5. These results are confirmed with Ahmad, (2002), Abdalla et al., (2011), El-Zohiri and Farag (2014) Youssef and Tony (2014) and Choudhary (2015) on garlic.

With regard to the effect of pre-sowing soaking cloves treatments, on bulb yield grades (from one to four grades), exportable, marketable and total yield of garlic bulb, data in Table 7 show that, there were significant differences between applications for most studied characters in both seasons. Pre-planting soaking cloves in $\mathrm{GA}_{3}$ followed by soaking in yeast extract in the second rate gave the highest values of bulb yield weight of $1^{\text {st }}$ grade (diameter of bulb more than $5.5 \mathrm{~cm}$ ) in both seasons and $2^{\text {nd }}$ grade in the first season only. On the other hand, the lowest values of yield weight of $3^{\text {rd }}$ and $4^{\text {th }}$ grade were obtained by soaking garlic cloves in $\mathrm{GA}_{3}$ before planting. Obtained results could be attributed

to the positive impact of $\mathrm{GA}_{3}$ on vegetative growth which improves assimilate capacity of the plants and thereby resulted in higher bulb yield. These results are in accordance with those reported by Ahmed and Hemada (2012), Woldeyes (2017) on garlic and Geletie (2016) on potato.

With regard to the effect of potassium treatments, data presented in Table 7 illustrate that potassium fertilizer sources and application methods had significant effect on all studied parameters compared with the control. Spraying potassium humate with $48 \mathrm{~kg} \mathrm{~K}_{2} \mathrm{O}$ as soil dressing increased 
significantly the $1^{\text {st }}$ and $2^{\text {nd }}$ grades yield, exportable, marketable, total yield (ton/fed) in the first and second seasons. On the other hand, the lowest 
results in this respect mostly obtained by added $48 \mathrm{kgK}_{2} \mathrm{O} /$ fed as soil application and spraying plants with liquid potassium $\left(37.5 \mathrm{~K}_{2} \mathrm{O}\right)$. The stimulative effect of potassium may be refer to that, it plays a vital role in enhancing sugar translocation, which consequently increases bulb weight and diameter. Also, the increment of dry matter accumulation in bulb by potassium application could be attributed to higher synthesis and translocation of photosynthates from the leaves to the bulb,which resulted to more accumulated dry matter and over total yield (Nardi et al., 2002 Atkin and Macheral, 2009 and Pal et al., 2016). Furthermore, applied plants with sulphur through the treatments potassium sulphate (as soil dressing) or thiosulphate (as foliar spray) affect the yield and quality of the crop as it performs many physiological functions like synthesis of various proteins, vitamins and co-enzymes (Choudhary, 2015) as well as increased chlorophyll amount in plant (Zeinali and Moradi, 2015). These results of the effect of different sources of potassium on total yield and its grades are agreed with those reported by Mahmoud, and Youssif, (2015), Zeinali and Moradi (2015)and Mohsen et al., (2017)regarding potassium humate on garlic, moreover, potassium sulfate or thiosulphate, Mansour et al., (2013) and Shafeek et al., (2015) on garlic and Behairy et al., (2015) on onion. As for potassium oxide Ahmed et al., (2010)and El-Bassiony (2006) on garlic and onion, respectively suggested that potassium application increased and improved the yield and quality of alliace plants particularly garlic.

\section{Interaction effect between planting date and soaking cloves treatments:}

Data in Table 8 show that interaction between planting date and presowing soaking of cloves had mostly significant effects on yield fractions and its grades in both seasons. In this respect, data show that pre-sowing treatment by soaking cloves of sides -40 cultivar in $250 \mathrm{ppm}$ of $\mathrm{GA}_{3}$ and plantation in $15^{\text {th }}$ Sep. gave the highest values of weight of $1^{\text {st }}$ grade, exportable, marketable and total bulb yield (ton/fed) in the first and second seasons of study. Moreover, soaking cloves in water gave the highest values of weight yield of $3^{\text {rd }}$ and $4^{\text {th }}$ grade during the two seasons.

These results are in accordance with those reported by Ahmed, (2002) who found that early sowing produced the highest quantity and quality of yield.

\section{Interaction effect between planting date and potassium treatments:}

Regarding to the interaction effect between planting date and potassium sources and application methods, there were significant differences in all studied parameters of yield and its grades (ton/fed) in both growing seasons 
(Table 8 ). The highest values of $1^{\text {st }}, 2^{\text {nd }}$ grades, exportable, marketable and total yield ton/fed were obtained when cloves were sown in $15^{\text {th }}$ Sep., fertilized 
with $48 \mathrm{~kg} \mathrm{~K} 2 \mathrm{O} / \mathrm{fed}$ as soil dressing and sprayed plants with potassium humate or thiosulphate.

\section{Interaction effect between soaking cloves and potassium treatments:}

Data in Table 8 indicate that soaking cloves pre-planting, combined with applied plants with various potassium sources and application methods had significant effects on exportable, marketable, total yield (ton/fed), as well as the weights of bulb grades from $1^{\text {st }}$ to $4^{\text {th }}$ grade during both growing seasons. The best results of the weight of bulb, at $1^{\text {st }}$ and $2^{\text {nd }}$ grades, total, exportable and marketable yield (ton/fed) in the fist and second seasons were obtained by soaking cloves in $250 \mathrm{ppm} \mathrm{GA}$ as pre-sowing treatment, applied plants with $48 \mathrm{~kg} \mathrm{~K}_{2} \mathrm{O} / \mathrm{fed}$ (soil dressing) in combination by $3 \mathrm{mlL}^{-1}$ of potassium humate as foliar fertilizer.

\section{Chemical composition of plant and cloves}

a) Chemical composition of plant (foliage + bulb):

Data in Table 9 illustrate the effect of planting date on the chemical composition of plant and cloves, i.e. $\mathrm{N}, \mathrm{P}, \mathrm{K}$ as well as percentage carbohydrates content in cloves. Obtained results show that there were significant differences between the two sowing dates for all studied chemical composition except potassium content of cloves in the first season and of plant in the second one. Results also show that, the early planting date $\left(15^{\text {th }}\right.$ Sep.) gave the maximum values of $\mathrm{N}, \mathrm{P}$ and $\mathrm{K}$ content of plant, as well as the highest nutritive quality especially in $\mathrm{N}, \mathrm{P}, \mathrm{K}$ and carbohydrates percentage of cloves in the two tested growing seasons. This promoting effect might be due to the favourable environmental conditions prevailed in $15^{\text {th }}$ Sep. which resulted vigorous vegetative and bulb growth, as well as, encourage the efficiency of roots to absorbed more nutrients from soil (Choudhary, 2015). These results are in conformity with those obtained by Ahmed, (2002) and El-Zohiri and Farag (2014) on garlic.

As for soaking cloves treatments, data presented in Table 9 show the effect of pre-soaking garlic cloves on gibberellic acid, yeast extract and water (control) on N, P and K content of plant (leaves + bulbs), as well as, the same elements and carbohydrates percentage in cloves. The highest values of macro-elements content were obtained when soaking cloves in $\mathrm{GA}_{3}$ at $250 \mathrm{ppm}$ followed by the treatment soaking in yeast extract in the second rank compared with the control (water). These results were true in both seasons. 
Such increments of soaking cloves in $\mathrm{GA}_{3}$ may be refer to that application of growth promoter $\mathrm{GA}_{3}$ can affect the vegetative growth and consequently led to enhance metabolic activities and accumulate these elements in different parts of plants as well as carbohydrates in bulbs. (Ouzounidou et al., (2011) and Helaly et al., (2016).

The positive effect of yeast extract on the increase of plant content of $\mathrm{N}, \mathrm{P}$ and $\mathrm{K}$ as well as the percentage of these minerals beside carbohydrates in cloves was attributed to its own contents of many important nutrients elements $(\mathrm{N}, \mathrm{P}$ and $\mathrm{K})$, high percentage of protein, large amount of vitamin $\mathrm{B}$ and natural plant growth regulators (Auxins, giberllins and Cytokinins), which promoted vegetative growth, increased photosynthesis and other metabolic processes which reflected on the chemical composition of either plants or garlic bulbs (Barnett et al., (1990) Twifiq (2010) and Kahlel (2015).

The same data presented in Table (9) show significant effects of various potassium sources which applied in soil or s foliar spray on $\mathrm{N}, \mathrm{P}, \mathrm{K}$ content in garlic plant (leaves + bulb) and $\mathrm{N}, \mathrm{P}, \mathrm{K}$ as well as carbohydrates content of bulb after curing. The highest values in this respect was obtained from the treatment $48 \mathrm{Kg} \mathrm{k} 2 \mathrm{O} / \mathrm{fed}$ as soil dressing with foliar spray of potassium humte or thiosulphate compared with the control.. These results were true in both seasons. These increments in the percentage of $\mathrm{N}, \mathrm{P}$ and $\mathrm{K}$ in plant as well as bulb of yield may be attributed to the role of potassium in plant metabolism and many important regulatory process in the plant which increase the mineral uptake by plants (Marschner, 2012). The highest values of chemical composition variables obtained by spraying potassium humate or by potassium theiosulphate may be attributed to the quickly absorption by plant surface especially leaves of the two compounds and its elements components as well as their translocation within the plant parts (Marschner, 1995). In this respect, Samson and Visser (1989) reported that humic acid induced increase in permeability of bio-membranes for electrolytes accounting for increase uptake of potassium. Moreover, Verlinden et al., (2009) suggested that potassium humate contains many elements necessary to the plant life and the mechanism of possible growth promoting effect may be attributed to hormone-like substances impact, activation of photosynthesis and improved nutrient uptake. As for potassium thiosulphate, the improvement in the plant chemical composition and nutritional cloves tissues could be attributed to the mode of action of sulphur in increasing net assimilation rate of nitrogen, higher content of $\mathrm{P}$ and $\mathrm{K}$ as well as enhanced photosynthesis which resulted in increased accumulation of carbohydrates content in garlic bulbs (Choudhary, 2015). 
These results are in accordance with the findings of El-Bassiony (2006), El Sayed and El-Morsy (2012), Abdel-Razzak and El-Sharkawy (2013), Denre et al., (2014) Mahmoud, and Youssif, (2015), Zeinalia and Moradi (2015), Shafeek et al., (2015) and Mohsen et al., (2017) all working on garlic.

Interaction effect between planting date and soaking cloves treatments:

Data in Table 10 show that the interaction between planting date and soaking treatments had significant effect on the studied chemical composition of plants and cloves. These results were true during both seasons of study except phosphorus content of plant in the first season. In general, the chemical composition either of plant or cloves gave the highest values of chemical composition when soaking cloves in $\mathrm{GA}_{3}$ or yeast extract and planted in $15^{\text {th }}$ Sep. This might be due to suitable environmental conditions (temperature and photopheriod) in $15^{\text {th }}$ Sep. planting and soaking gloves in $\mathrm{GA}_{3}$ caused vigorus vegetative as well as bulbs growth and development. Furthermore, the efficiency of plant roots to absorb the nutrients from soil may be increased which reflect on the assimulation and accumulation the products of plant and yield quality (Ahmed and Hemada, 2012 and Choudhary, 2015).

\section{Interaction effect between planting date and potassium treatments:}

Data in Table 10 recorded that all interactions between the two planting dates and various potassium sources and application methods showed statistical variation on N, P and K content in plants and cloves as well as carbohydrates percentage in garlic cloves. The highest values of chemical composition content for plant and cloves were obtained by sowing in $15^{\text {th }}$ Sep. and added $48 \mathrm{~kg} \mathrm{~K}_{2} \mathrm{O} /$ fed as soil dressing and spray plants with potassium humate or thiosulphate. Similar results were also stated by Choudhary (2015) who reported that sulphur (which found in thiosulphate) might have helped in increasing net assimilation rate of nitrogen, $\mathrm{P}$ and $\mathrm{K}$ content as well as accumulation of carbohydrates content of garlic bulb. These results are in accordance with the findings of Ahmed et al., (2010), Denre et al., (2014).

\section{Interaction effect between soaking cloves and potassium treatments:}

Data in Table 10 show significant differences between the combinations between soaking cloves and different potassium sources and application methods of all studied chemical composition contents in plant and cloves during the two growing seasons. Such data indicate that presowing soaking gloves in $\mathrm{GA}_{3}$ and fertilized the plants with $48 \mathrm{~kg} \mathrm{~K}_{2} \mathrm{O} / \mathrm{fed}$ and spraying potassium humate or thiosulphate increased the concentration 
of $\mathrm{N}, \mathrm{P}$ and $\mathrm{K}$ in plant and cloves, as well as, carbohydrates percentage in cloves.

\section{Storability of garlic bulbs:}

Data in Table 11 show significant effects of planting date on weight loss of garlic bulbs during storage period ( 9 months). After 270 days from the beginning of storage late planting date $\left(1{ }^{\text {st }}\right.$ Oct.) showed the highest weight loss (33.67 and 33.39\%), while the lowest weight loss (31.33 and 30.97\%), were recorded by early planting $\left(15^{\text {th }}\right.$ Sep.), during first and second season, respectively. These results agree with those reported by Ahmad, (2002) and Hassan et al., (2016) who found that there were gradual increase in bulb weight loss percentage during storage period and this may be affected with cultivar, planting date and period of curing.

With respect to the effect of pre-planting soaking cloves on weight loss percentage, data in Table 11 show clearly that all treatments which received $\mathrm{GA}_{3}$, yeast extract and water as pre-sowing soaking cloves increased the weight loss gradually from the first to the last month during storage period ( 9 months). In this respect, soaking cloves at $250 \mathrm{ppm}$ of $\mathrm{GA}_{3}$ or the yeast extract in the second order proved to be the best treatments on bulb weight loss than the control (water). Obtained results are in agreement with those found by Tartoura and EL-Saei (2006), Abd El-Mageed et al. (2009) and El-Morsy et al. (2011), who indicated that sprayed plants with yeast extract improved the bulb storability than the untreated plants.

As for the effect of different sources of potassium and application methods on weight loss of garlic bulb during storage, data presented in Table 11. indicate that adding potassium fertilizer at $48 \mathrm{~kg} \mathrm{~K}_{2} \mathrm{O} / \mathrm{fed}$ as soil dressing with spraying garlic plants by $3 \mathrm{mlL}^{-1}$ of potassium humate followed by potassium thiosulphate treatment in the second order recorded the lowest values of weight loss percentage after 270 days from the beginning of storage period compared with the control and other treatments in both seasons. Obtained results probably attributed to the enhancing effect of potassium humate and thiosulphate on vegetative growth characters, photosyntehsis process which releated with high dry matter content of bulbs and this may be reflected on improvement the quality and storability of garlic bulbs during storage (Ahmed et al., 2010). In addition, Ali and Taalab (2008) stated that the stimulative effect may be due to the role of potassium on enzymes promotion activity as well as enhancing translocation of assimilates and protein. Such results are agree with those reported by ElSayed and El-Morsy (2012) and Abdel-Razzak and El-Sharkawy (2013) on garlic. 


\section{Interaction effect between planting date and soaking cloves treatments:}

Data in Table 12 clearly show that the interaction between planting date and soaking treatments had significant effects on weight loss of bulbs during the storage period of both seasons. It is obvious from data that, the highest values of bulb weight loss were recorded at the last four months of storage period when the cloves soaked in yeast extract and planted in $1^{\text {st }}$ Oct. obtained results are in agreement with those reported by Hassan et al., (2016).

\section{Interaction effect between planting date and potassium treatments.}

In this respect results in Table 12 indicate that the increase in weight loss of bulbs started after 180 days from the beginning of storage period by planting cloves in $1^{\text {st }}$ oct. and fertilized with $96 \mathrm{Kg} \mathrm{K} \mathrm{K}_{2} \mathrm{O} /$ fed in the form of potassium sulphate and applied as soil dressing. On the other hand, the lowest weight loss of stored bulbs in the same period were recorded by planting garlic cloves in $15^{\text {th }}$ Sep. and fertilized with $48 \mathrm{~kg} \mathrm{~K} \mathrm{~K}_{2} \mathrm{O} /$ fed as application soil combined with potassium humate as foliar spray. These results may be attributed to the enhanced effect of potassium humate on growth characters which may be reflected on improved the quality and storability of garlic bulbs (Ahmed et al., 2010). In this concern, the stimulative effect probably due to the role of potassium on enzymes promotion activity and enhancing the translocation of assimilates and protein (Ali and Taalab, 2008).

\section{Interaction effect between soaking cloves and potassium treatments:}

Regarding the interaction effect between soaking treatments and potassium sources and applications, there were significant effect of treatments on bulb weight loss during storage period as shown in Table (12). Data reveale that the minimum weight loss of stored bulb were recorded by soaking gloves in $\mathrm{GA}_{3}$ at $250 \mathrm{ppm}$ and supply plants with $48 \mathrm{~kg} \mathrm{~K} 2 \mathrm{O} / \mathrm{fed}$ as soil dressing and sprayed plants with $3 \mathrm{mlL}^{-1}$ potassium humate. These results agree with those suggested by Ahmed and Hemada (2012) and Shafeek et al., (2015).

\section{Conclusion:}

Planting date and pre-sowing soaking treatments as well as different forms and application methods of potassium fertilizers play an important role on the improvement of growth, bulb yield and quality, as well as, its storability of garlic. Early sowing date $\left(15^{\text {th }}\right.$ Sep.) showed enhancing effects on germination percentage and number of days to its seedling growth, hence the plants will have a suitable growth period before bulbing and this reflected on better bulb formation and quality. Pre-sowing treatments by 
soaking garlic cloves in a solution of gibberellic acid $(250 \mathrm{ppm})$ for 12 hours had the best results of cloves germination percentage and early emergence, as well as it enhanced morphological traits, yield and its components, chemical composition of plants and cloves, as well as the storability of bulbs. Foliar spray of potassium humate or thiosulphate with $48 \mathrm{kgK}_{2} \mathrm{O} /$ fed as soil dressing showed superior performance on all studied characters. The best interaction for improved garlic plant growth, bulb weight and total yield and its quality as well as decreasing weight loss of bulbs during storage was obtained by sowing garlic cloves at $15^{\text {th }}$ Sept. after soaking in a solution of $\mathrm{GA}_{3}$ at $250 \mathrm{ppm}$ for $12 \mathrm{hrs}$. and spraying plants with $3 \mathrm{mlL}^{-1}$ of potassium humate or thiosulphate plus adding $48 \mathrm{~kg}$ $\mathrm{K}_{2} \mathrm{O}$ /fed (half recommended dose of potassium fertilizer) as soil dressing.

\section{REFERENCES:}

Abd El-Mageed, I.Y.T., N.S. Youssef and Youssef Shereen M. (2009). Effect of some anti oxidant sources on growth, yield and storability of garlic. Egypt J. Agric. Res., 87 (1): 245-264.

Abdalla, M.M. A., M.H. Aboul-Nasr, A.K. Metwaly and S.H. Ali (2011). Growth and yield of fifteen garlic ecotypes. Assiut J. Agric. Sci., 36 (5): 52-65.

Abdel-Razzak, H.S. and G.A. El-Sharkawy (2013). Effect of biofertilizer and humic acid applications on growth, yield, quality and storability of two garlic (Allium sativum L.) cultivars. Asian J. Crop Sci., 5(1):48-64.

Abu-Rayyan, A., M.W. Akash and G. GInqinto (2012). Onion seed germination as affected by temperature and light. Int. J.Veg. Prod., 10, 37-49.

Ahmad, Omaima O. M.(2002): Physiological studies on garlic Crop.; M.Sc. Thesis, Hort. Dept. Fac. Agric., Zagazig Univ., Egypt.

Ahmed, M.E. M., A.A. El-Aidy, E.A. Radwan and T.S. Abd El-Bary (2010). Response of garlic plants to humic acid and different application methods of potassium fertilizer. Minufiya J. Agric. Res., 35 (6): 1-17.

Ahmed, S.I. and A.A. Hemada (2012). Effects of pre-planting treatments of garlic (Allium sativum L.) cloves on growth and yield under middle Egyption conditions. J. Plant Prod. Mansoura Univ., 3(6): 971-993.

Ali, A.H. and A.S. Taalab (2008). Effect of natural and/or chemical potassium fertilizers on growth, bulbs yield and some physical and chemical constituents of onion (Allium sepa L.). Res. J. Agric. \& Biol. Sci., 4 (3): 228-237.

Amagase, H. (2006). Clarifying the real bioactive constituents of garlic. J. Nutr., 131:7165-7255. 
Atkin, O.K., D. Macherel (2009). The crucial role of plant mitochondria in orchestrating drought tolerance. Ann. Bot., 103: 581-597.

Barnett, J.A., R.W. Payne and D. Yarrow (1990). Yeasts. Characteristics and identification. Cambridge University Press, London, pp: 999.

Behairy, Awatef G., Mahmoud Asmaa R., M.R. Shafeek, Ali Aisha H. and Hafez Magda M. (2015). Growth, yield and bulb quality of onion plants (Allium cepa L.) as affected by foliar and soil application of potassium. Middle East J. Agric. Res., 4 (1): 60-66.

Black, C.A. (1982). Methods of soil Analysis. Part 2, Amer. Soc. Agron., INC, Publisher, Madison, Wisconsin, USA.

Bremner, J.M. and C.S. Mulvaney (1982). Total nitrogen, In: Page, A.L., R.H. Miller and D.R. keeney (Eds). Methods of soil Analysis. Part 2, Amer. Soc. Agron. Madison, Wisconsin USA, pp.595-624.

Chen, Y. and T. Avaid (1990). Effects of humic substances on plant growth, in: Humic Substances in Soil and Crop Sciences: Selected Readings (P. Mac Carthy, C.E. Clapp, R.L. Malcolm and P.R. Bloom (Eds), ASA and SSSA, Madison, Wisconsin, USA, pp: 161-186.

Chen, Y., C. Clapp and H. Magan (2004). Mechanism of plant growth stimulation by humic substances: The role of organo-iron complexes. Soil Sci. Plant Nutr., 50: 1089-1095.

Choudhary, K. (2015). Effect of sowing time and sulphur levels on growth, yield and quality of garlic (Allium sativum L.). M. Sc. Thesis, Fac. Agric., Sri Karan Narendra Agric. Univ., Jobner,India.

Denre, M., G. Soumya and S. Kheyali (2014). Effect of humic acid application on accumulation of mineral nutrition and pungency in garlic (Allium sativum L.). Int. J. Biotechnol. Mol. Biol. Res., 5 (2):7-12.

Dubois, M., K.A. Gilles, J.K. Hamilton, P.A. Robers and F. Smith (1956). Calorimetric methods for determination of sugars and related substances. Anlyt. Chem., 28: 350.

El-Bassiony, A.M. (2006). Effect of potassium fertilization on growth, yield and quality of onion plants. J. Appl. Sci. Res., 2 910): 780-795.

El-Desouky, S.A., A.L. Wanas and Z.M.A. Khedr (1998). Utilization of some natural plant extracts (of garlic and yeast) as seed-soaked materials to squash (Cucurbita pepo L.). I-Effect on growth, sex expression and fruit yield \& quality. Ann. Agric. Sci. Moshtohor, Zagazig Univ., 25 (2): 839-854.

El-Hamady, M.M. (2017). Growth and yield of potato Solanum tuberosum L. as influenced by soaking in $\mathrm{GA}_{3}$ and potassium fertilizer rates. Canad. J. Agric. \& Crops, 2(1): 50-59. 
El-Helaly, M. A. and S. S. Karam (2012). Influence of planting date on the production and quality of onion seeds, J. Hort. Sci. \& Orn. Plants, 4 (3): 275-279.

El-Morsy, A.H.A., U.M.Saif El-Deen and A.S. Ezzat (2011). Response of growth, productivity and storability of garlic (Allium Sativum L.) to foliar spray with magnesium and yeast extract. J. Plant Prod., Mansoura Univ., 2(1): 39-51.

El-Sayed, H.A. and A.H.A. El Morsy (2012). Response of productivity and storability of garlic (Allium Sativum L.) to some potassium levels and foliar spray with mepiquat Chloride (PIX). Int. Res. J. Agric. Sci. Soil Sci.,, 2 (7): 298-305.

El-Sharkawy, Gehan A. (2013). Growth, yield and chemical composition of peas (Pisum sativum) as affected by potassium levels and different methods of yeast application. Alexandria Sci. Exchange J., 34 (4): 360-368.

El-Zohiri, S.S. M. And A.A. Farag (2014). Relation planting date, cultivars and growing degree-days on growth, yield and quality of garlic. Middle East J. Agric. Res., 3 94): 1169-1183.

FAO (2014). Production Yearbook International production of garlic. Food and Agriculture Organization (FAO), Rome, Italy.

Geletie, K.A. (2016). Effect of Gibberellic acid and cytokinin on tuber dormancy and subsequent growth and yield of potato (Solanum tuberosum L.) at southastern Ethiopia. M.Sc. Thesis, School of Graduate Studies, Haramaya Univ., Haramaya.

Glick, B.R. (1995). The enhancement of plant growth by free living bacteria, Canada J, Microbiology, 41;109-117.

Hassan, G.H. , M.A. El-Shal, KH.A. Soliman and I.M. Ghoneim (2016). Effect of planting dates and periods of curing on quantitative, qualitative characteristics and storage ability of two garlic cultivars. J. Agric. Kafr El-Sheikh Univ., 42 (3): 401-414.

Haytova, D. (2013). A Review of foliar fertilization of some vegetables crops. Ann. Rev. Res. Bio, 3 94): 455-465.

Helaly, A.A., M.S. Abdeloghafar, M.T. Al-bd and A.A. Alkharpotly (2016). Effect of soaked Allium cepa L. bulbs in growth regulators on their growth and seed production. Adv. Plants Agric. Res., 4(3): 139-145.

Huber, S.C. (1985). Role of potassium in photosynthesis and respiration pp: 369-396. In, Potassium in Agriculture. Amer. Soc. Agron., Madison, WI.

Ismaeil, Faten H.M. and K.H.A. Bakry (2005). Response of papaya plants to some chemical substances and yeast extract treatments. https:// www. Research gate. Net/publication/282504992. 
Jackson, M. L. (1970). Soil Chemical Analysis. Prentic Hall, Inc. Englewood Cliffs, new Jeresy, pp.498.

John, L. J. and G.E. Lester (2011). Effect of foliar Potassium fertilization and source on cantaloupe yield and quality. Better Crops, 95 (1): 13-15.

Kahlel, A.M.S. (2015). Effect of organic fertilizer and dry yeast on growth and yield of potato (Solanum tuberosum L.), J. Agric. Food Tech., 5(1): 5-11.

Kolota, E. and M. Osinska (2001). Efficiency of foliar nutrition of field vegetables grown at different nitrogen rates. Acta Hortic, 563:87-91.

Kraig, E. and J.E. Hober (1980). Messenger ribonucleic acid and protein metabolism during sporulation of Saccharomyces cerevisiae. J. Bacterial., 144: 1098-1112.

Mahmoud, Hosna A. F. and B.D. Youssif, Shadia (2015). Response of garlic (Allium sativum L.) to natural fertilizers and Ores under Ras Sudr conditions. Middle East J. Appl. Sci., 5 94): 1174-1183.

Mann, L.K. (1952). Anatomy of garlic bulb and factors affecting bulb development. Hilgardia, 21 (8): 195-231.

Mansour, M. A., A.A Gad, A.Bardisi and H.E.M.A. Ismail (2013). Growth and productivity of garlic plants as affected by nitrogenous and potassium fertilization, Zagazig J. Agric. Res., 40(6): 1059-1070.

Marschner, H. (1995). Mineral nutrition of higher plants. Academic Press, London, pp.889.

Marschner, P. (2012). Marschner's mineral nutrition of higher plants, $3^{\text {rd }}$ ed. Academic Press, London, p.672.

Mengel, K. and A. Kirkby (1987). Principles of Plant Nutrition. International Potash Institute, Norblafen-Bern, Switzerland.

Ministry of Economic, Egypt (1963). To Control Exported Garlic. Ministerial order No. 652.

Mohsen, A.A. M., S.Kh. A. Ibraheim and M.K. Abdel-Fattah (2017). Effect of potassium humate, nitrogen bio fertilizer and molybdenum on growth and productivity of garlic (Allium sativum L.). Curr. Sci. Int., 6(1): $75-85$.

Nardi, S., D. Pizzeghello, A. Muscolo and A. Vianello (2002). Physiological effects of humic substances in plant growth. Soil Biol. Biochem., 34 (11): 1527-1536.

Olsen, S.R. and L.E. Sommers (1982). Phosphorus. In: Methods of soil Analysis, Part 2. Amer. Soci. Agron., Madison, WI. USA, pp:403-430.

Ouzounidou, G., A. Giannakoula asnd M. Asfi (2011). Differential responses of onion and garlic against plant growth regulators. Pakistan J. Bot., 43 (4): 2051-2057. 
Pal, P., K. Yadav, K. Kumar, N. Singh (2016). Effect of Gibberellic acid and potassium foliar sprays on productivit6y and physiological and biochemical parameters of parthenocarbic cucumber cv. Seven star $F_{1}$. J. Hort. Res., 24(1): 93-100.

Pallant, J. (2001). SPSS Survival Manual: A step by step Guide to Data analysis using SPSS For Windows [Version 10], Allen and Vnwin.

Pettit, R.E (2009). Organic matter, humus, humate, humic acid, fulvic acid and humin, Monty's Plant Food Co., Inc. USA.

Rahim, M.A., M.N.A Chowdhury, H.R.M.M. Anwar and M.S. Alam (2003). Effect of planting dates on the growth and yield of garlic germplasm. Asian J. of plant Sci, 2(2): 171-174.

Rahman, H.M., S.M. Haquel, A.M. Karim and A.Ahmed (2008). A. Effects of Gibberellic acid on breaking dormancy in garlic (Allium sativum L.). Int. J. Agric. \& Bio., 1560 (1): 63-65.

Rahman, M.H., M.S. Haque, M.A. Karim and M. Ahmed (2006). Effects of gibberellic acid $\left(\mathrm{GA}_{3}\right)$ on breaking dormancy in garlic (Allium sativum L.). Int. J. Agric. Biol., 8 (1): 63-65.

Ray Noggle, G. and G.J. Fritz (1992). Introductory Plant Physiology $2^{\text {nd }}$ ed. Prentice Hall of India, New Delhi.

Salama, A.S.M. (1998). Studies on growth and flowering of papaya. M.Sc. Thesis, Fac. Agric. Moshtohor, Zagazig Univ., Egypt.

Saleem, M.S., M.Sajid, Z. Ahmed, S.Ahmed, N. Ahmed and M.S.U. Islam (2014). Effect of seed soaking on seed germination and growth of bitter gourd cultivars. Iosr. J. Agric. \& Veterinary Sci., 6(6):7-11.

Samson, G. and S.A. Visser (1989). Surface-active effect of humic acids on potato cell membrane properties. Soil bio. Biochem. Bern, 21: 343-347.

Shafeek, M.R. , Ali Aisha H., Mahmoud Asmaa R., Hafez Magda M. and F.A. Rizk (2015). Improving growth and productivity of garlic plants (Allium sativum L.) as affected by the addition of organic manure and humic acid levels in sandy soil conditions. Int. J. Curr. Microbiol. Appl. Sci., 4(9): 644-656.

Shafeek, M.R., Ali Aisha H., Mahmoud Asmaa R. and Hafez Magda M. (2016). The influence of foliar and soil fertilization of potassium on growth, yield and quality of garlic plants (Allium sativum L.). Int. J. Pharm Tech. Res., 90 (9): 390-397.

Shafeek, M.R., Y.I. Helmy and Nadia M. Omar (2016). Effect of spraying or ground drench from humic acid on growth, total output and fruits nutritional values of cucumber (Cucumis sativus L.) grown under plastic house conditions. Int. J. Pharma Tech Res., 9 (12): 52-57. 
Shalaby, T.A. and H. El-Ramady (2014): Effect of foliar application of biostimulants on growth, yield, components and storability of garlic (Allium sativum L.). Australian J. Crop Sci., 8 (2): 271-275.

Subrata, C., P.K. Chattopadhyay and M.A. Hassan (2010). Dynamics of growth and yield of garlic in variable planting time and applied nutrient. Indian J. Hort., 67(3):348-352.

Swati, B., K.S. Kirad and A.K. Shrivastav (2013). Effect of planting dates on growth and yield on garlic (Allium sativum L.). Int. J. Hort., 3 94): 16-18.

Taha, A.A., M.M. Omar and R. K. Hadeer (2016). Effect of different sources and levels of potassium on growth, yield and chemical composition of faba bean plants. J. Soil Agric. Eng., Mansoura Univ., 78(3): 243-248.

Takagi, H. (1990). Garlic (Allium sativum L.) In: onions and allied crops, Bresgterv, J.L. and H.D. Rabinowitch (eds)k, volume (3). CRC Press, Inc., 109-146.

Tartoura, E.A.A. and M.A.El-Saei (2006). Effect of compost tea, yeast extract and their mixture on yield and storability period in garlic. J. Agric. Sci. Mansoura Univ., 31 (7): 4801-4811.

Twfiq, A.A. (2010). Estimation levels of indole acetic acid (IAA) and gibberellic acid $\left(\mathrm{GA}_{3}\right)$ in dry bakery yeast Saccharomyces ceveviciae. J. Bio-Tech. Res. Center, 4 (2): 94-100.

Verlinden, G., B. Pycke, J. Mertens, F. Debersaques, K. Verheyen, G. Baert, J. Bries and G. Haesaert (2009). Application of humic substances results in consistent increases in crop yield and nutrient uptake. J. Plant Nutr., 32: 1407-1426.

Wanas, A. L.W. (2002). Response of faba bean (Vicia faba L.) plants to seedsoaking application with natural yeast and carrot extracts as phytohormones and other growth. Factors-rich sources. Ann. Agric. Sci., Moshtohor, 40(1): 83-102.

Wanas, A.L. (2006). Response of squash plants grown in winter season to some natural extracts and antioxidants. Ann. Of Agric. Sci., Moshtohor, 44 (4): 1571-1591.

Woldeyes, F. (2017). Influence of low storage temperature and gibberellic acid treatments on growth and yield of garlic (Allium sativum L.) at Haramaya, eastern Ethiopia. J. Agric, and Ecology Res. Int., 10 (1): 1-13.

Woldeyes, F., K.W. tsadik and G.Tbor (2017). Emergence of garlic (Allium sativum L.) as influenced by low storage temperature and gibberellic acid treatments. J. Agric. And Ecology Res. Int., 10 (2): 1-7. 
Youssef, N.S. and H.S.H. Tony (2014). Influence of different planting date on the performance of new garlic genotypes grown under El-Minia governorate conditions. Nature and Sci., 12 (5): 112-119.

Zeinali, A. and P. Moradi (2015). The effects of humic acid and ammonium sulfate foliar spraying and their interaction effects on the qualitative and quantitative yield of native garlic (Allium sativum L.). J. Appl. Environ. Biol. Sci., 4 (12): 205-211.

\section{تأثير ميعاد الزراعة، معاملات النقع ما قبل الزراعة ومصادر وطرق

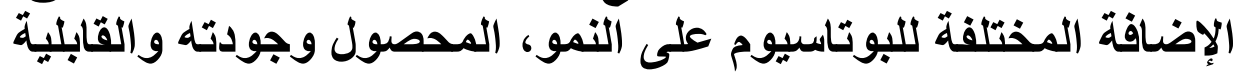 للتخزين في الثوم الثو،}

قسم الإنتاج النباتي - كلية التكنولوجياء والتنمئة - جامعة الزقازيق - ج.م.ع.

أجريت هذه التجربة بمزر عة التجارب بكلية التكنولوجيا والتنمية (غز الةــ

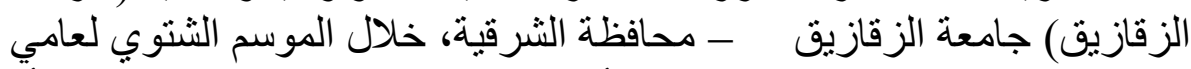

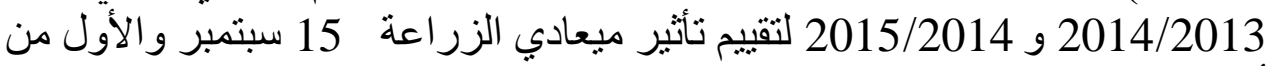

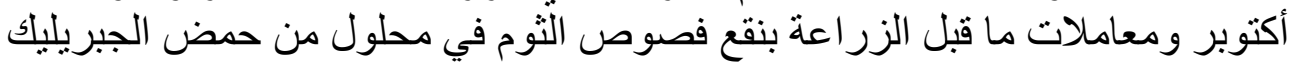

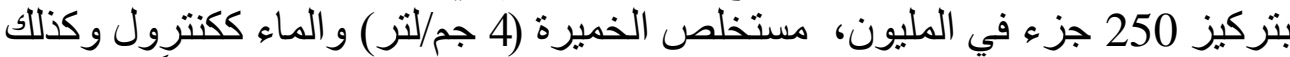

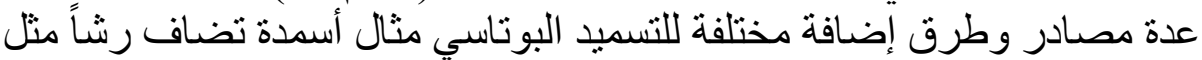

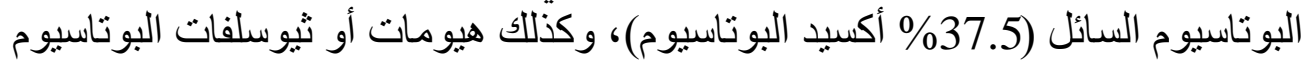

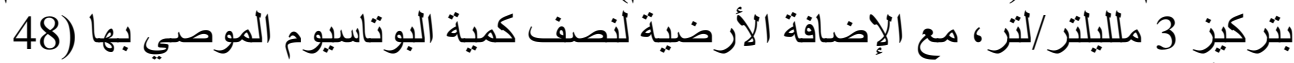

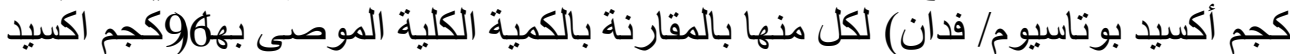

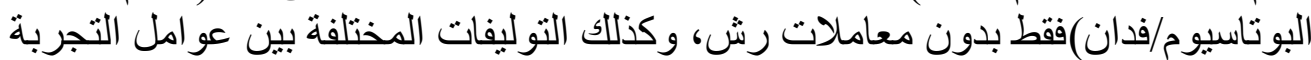

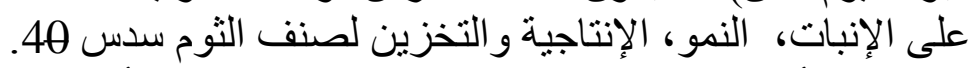

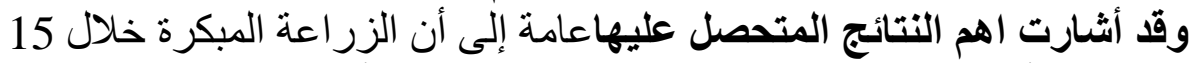

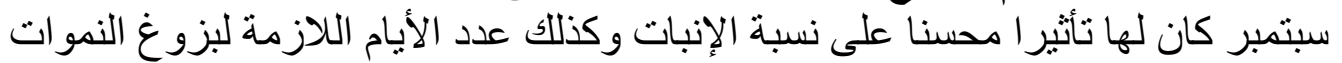

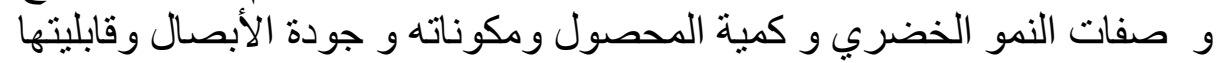

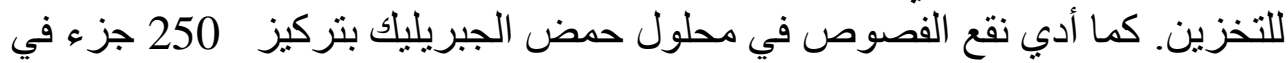

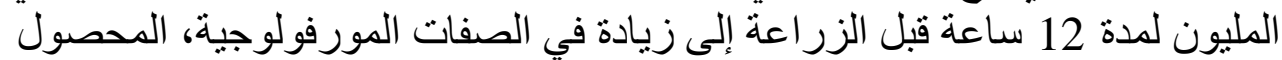

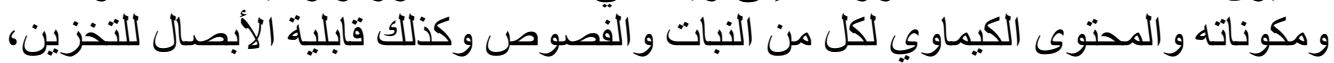

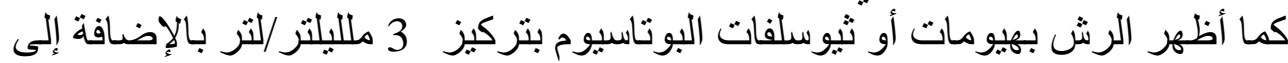

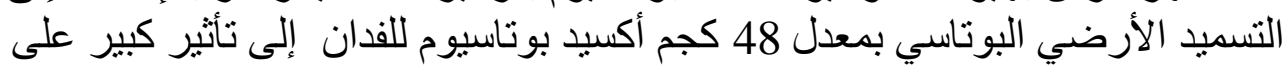




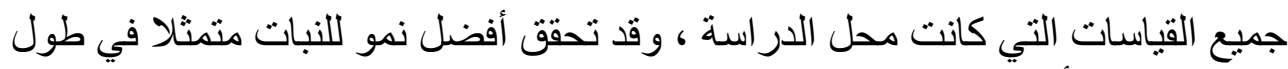

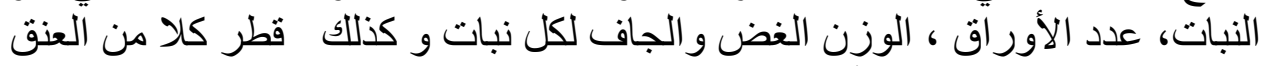

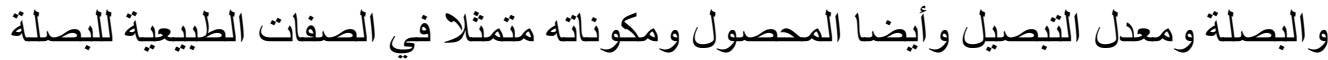

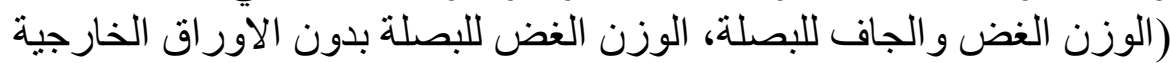

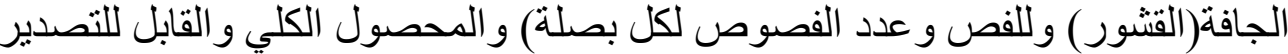

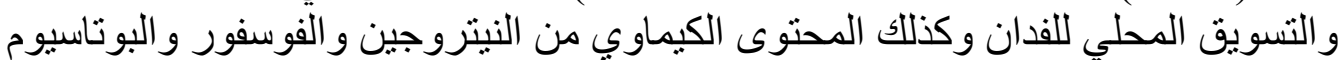

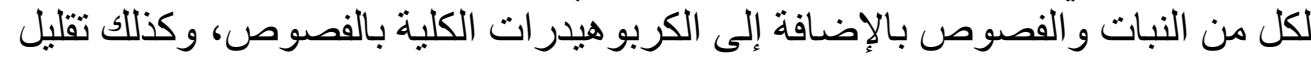

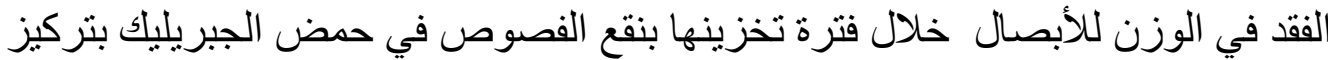

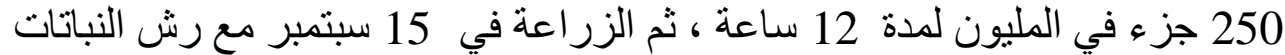

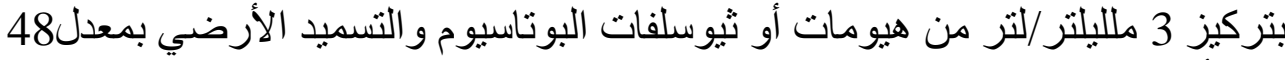

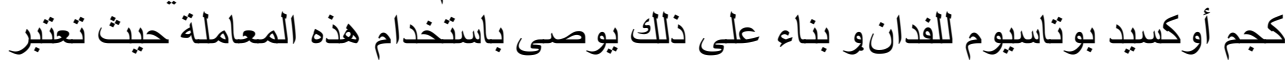

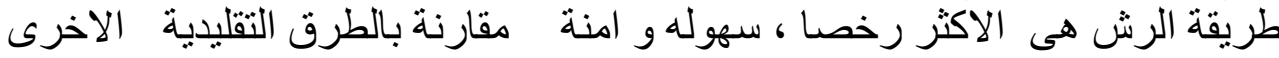
لاضافة الاسمدة البوتاسية لانتاج اعلى محصول و جودة الألى لنبات الثوم. 